\title{
Sistem Penunjang Keputusan Untuk Menentukan Status Gizi Balita Menggunakan Metode Fuzzy Tsukamoto
}

\author{
Dewi Ayu Nur Wulandari ${ }^{1}$, Arfhan Prasetyo ${ }^{2}$ \\ ${ }^{1}$ AMIK BSI Karawang \\ email: dewi.dan@bsi.ac.id \\ ${ }^{2}$ AMIK BSI Bogor \\ email: arfhan.afp@bsi.ac.id
}

\begin{abstract}
Abstrak
Masalah gizi anak masih menjadi masalah nasional. Ciri khas anak yang sehat harus dilihat dari tumbuh dan berkembang. Untuk memastikan bahwa perkembangan anak balita optimal dan untuk mengantisipasi malnutrisi yang dapat mempengaruhi balita, diperlukan teknik untuk menilai status gizi anak. Status gizi anak balita perlu dipantau terus menerus, karena status gizi balita dapat dijadikan ilustrasi kesehatan, pertumbuhan dan perkembangan anak. Untuk membantu dalam menentukan status gizi anak, diperlukan bantuan teknologi informasi. Sistem Pendukung Keputusan adalah sistem interaktif berbasis komputer yang dapat membantu pengambil keputusan dalam menggunakan data dan model untuk memecahkan masalah terstruktur dan tidak terstruktur. Fuzzy Tsukamoto adalah salah satu metode yang paling fleksibel dan toleran yang tersedia, dengan keuntungan yang lebih intuitif, diterima oleh banyak pihak, lebih sesuai untuk input yang diterima dari manusia daripada mesin, ia akan memfasilitasi pihak-pihak yang terlibat dalam memantau perkembangan dan perkembangan balita. Hasil penelitian ini berupa Sistem Pendukung Keputusan untuk mengetahui Status Gizi metode Fuzzy Tsukamoto berbasis Balita yang diharapkan dapat digunakan di posyandu untuk memantau pertumbuhan bayi balita sehingga anak-anak dengan status gizi kurang mendapatkan penanganan yang lebih baik dan lebih cepat. Hasil Penelitian menunjukkan akurasi metode tsukamote di bandingkan dengan metode antropometri dalam menentukan status gizi balita adalah sebesar $82,75 \%$.
\end{abstract}

Kata kunci: inferensi fuzzy, fuzzy tsukamoto, Status Gizi Balita

\begin{abstract}
Children's nutritional problems are still a national problem. Characteristic of healthy children should be seen from growing and developing. To ensure optimal development of children under five and to anticipate malnutrition that may affect children under five, a technique to assess the nutritional status of children is required. Nutrition status of toddlers needs to be monitored continuously because the nutritional status of children can be illustrated health, growth, and development of children. To assist in determining the nutritional status of children, information technology assistance is required. Decision Support System is a computer-based interactive system that can assist decision makers in using data and models to solve structured and unstructured problems. Fuzzy Tsukamoto is one of the most flexible and tolerant methods available, with more intuitive advantages, accepted by many, more suited to inputs received from humans rather than machines, it will facilitate the parties involved in monitoring the development and development of toddlers. The results of this research are Decision Support System to know the Nutritional Status of Fuzzy Tsukamoto-based Toddler method which is expected to be used in posyandu to monitor the growth of infants so that children with less nutritional status get better and faster handling. The result of the research shows the accuracy of tsukamoto method in comparison with anthropometry method in determining the nutritional status of children under five is $82,75 \%$
\end{abstract}

Keywords: fuzzy inference, fuzzy tsukamoto, the Nutritional Status of Toddler 


\section{Pendahuluan}

Status gizi anak merupakan hal yang penting yang harus diperhatikan oleh orang tua maupun pemerintah. Gizi anak merupakan cerminan kesehatan, perkembangan dan pertumbuhan anak. Masalah gizi buruk saat ini masih menjadi masalah nasional karena masih terjadi dibeberapa wilayah di Indonesia. Menurut data yang diungkapkan oleh Direktur Gizi Masyarakat Kementrian Kesehatan bahwa "Hasil Pemantauan Status Gizi (PSG) tahun 2015 didapat data $3,8 \%$ balita di Indonesia mengalami gizi buruk. Angka ini turun dari tahun sebelumnya yakni 4,7\%". Hal tersebut menunjukkan walaupun nilainya turun, tetapi masalah gizi buruk masih terjadi di Indonesia. PSG ini merupakan upaya yang dilakukan oleh pemerintah untuk perencanaan, penentuan kebijakan dan monitoring serta pengambilan tindakan intervensi dalam hal peningkatan gizi balita. (www.depkes.co.id)

Pada saat ini untuk mengetahui status gizi balita di masyarakat menggunakan Kartu Menuju Sehat (KMS). Metode ini membutuhkan ketelitian yang lebih untuk menentukan status gizi balita (Fitri et.al, 2013). KMS yang digunakan belum optimal dikarenakan masih sering terjadinya kesalahan pencatatan akibat hilangnya kartu KMS ataupun kesalahan pencatatan sehingga keadaan kesehatan balita tidak terpantau dengan baik yang dapat menyebabkan timbulnya kasus gizi buruk.Hal ini dapat menyebabkan status gizi anak mengalami kesalahan dan menimbulkan masalah gizi buruk karena kesehatan anak tidak dapat ditangani dengan cepat.

Beberapa penelitian menunjukkan bahwa gizi kurang pada balita membawa dampak negatif terhadap pertumbuhan fisik maupun mental, yang selanjutnya akan menghambat prestasi belajar. Akibat lainnya adalah penurunan daya tahan, sehingga kejadian infeksi dapat meningkat. Kekurangan gizi akan menyebabkan hilangnya masa hidup sehat balita. Dampak yang lebih serius adalah timbulnya kecacatan, tingginya angka kesakitan dan percepatan kematian (Rahim, 2014).

\section{Metode Penelitian \\ Tahapan Penelitian}

Agar pelaksanaan penelitian ini terarah dan sistematis, maka disusunlah tahapan-tahapan penelitian. Menurut Moleong (2007), ada empat tahapan dalam pelaksanaan penelitian yaitu sebagai berikut:

1. Tahap pra lapangan

Pada tahapan ini penulis mengadakan survei pendahuluan yakni dengan mencari subjek sebagai narasumber. Selama proses survei ini penulis melakukan kegiatan survey lapangan terhadap latar belakang masalah pembuatan penelitian, pencarian data dan informasi tentang proses dan kegiatan posyandu dalam hal pencatatan status gizi anak. Penulis juga menempuh upaya konfirmasi ilmiah melalui penelusuran literatur buku dan referensi yang mendukung penelitian. Pada tahap ini penulis melakukan penyusunan rancangan penelitian yang meliputi garis besar metode penelitian yang akan digunakan dalam melakukan penelitian. Peneliti juga menyiapkan perlengkapan penelitian. Dalam tahapan ini diharapkan peneliti mampu memahami latar belakang penelitian dengan persiapan-persiapan diri yang mantap untuk masuk dalam lapangan penelitian.

2. Tahap pekerjaan lapangan

Dalam tahap ini peneliti berusaha mempersiapkan diri untuk menggali dan mengumpulkan data-data untuk dibuat suatu analisis data mengenai penentuan status gizi balita. Secara intensif setelah mengumpulkan data, selanjutnya data akan dikumpulkan dan disusun untuk proses selanjutnya.

3. Tahap analisis data

Dalam tahapan yang ketiga ini, penulis melakukan serangkaian proses analisis data sampai pada interpretasi data-data yang telah diperoleh sebelumnya. Selain itu penulis juga menempuh proses triangulasi data yang diperbandingkan dengan teori kepustakaan.

4. Tahap evaluasi dan pelaporan

Pada tahap ini penulis melakukan pemeriksaan ulang terhadap proses analisa data yang telah dilakukan sebelumnya, untuk meminimalisasi kesalahan yang mungkin akan muncul pada saat pembuatan laporan. 


\section{Logika Fuzzy}

Menurut kusuma dewi dan purnomo (2010) Logika fuzzy merupakan salah satu komponen pembentuk softcomputing. Logika fuzzy pertama kali diperkenalkan oleh Prof. Lotfi A. Zadeh pada tahun 1965. Dasar logika fuzzy adalah teori himpunan fuzzy. Pada teori himpunan fuzzy, peranan derajat keanggotaan sebagai penentu keberadaan elemen dalam suatu himpunan sangatlah penting. Nilai keanggotaan atau derajat keanggotaan atau membership function menjadi ciri utama dari penalaran dengan logika fuzzy tersebut.

Logika fuzzy umumnya diterapkan pada masalahmasalah yang mengandung unsur ketidakpastian (uncertainty), ketidaktepatan (imprecise), noisy, dan sebagainya. Logika fuzzy menjembatani bahasa mesin yang presisi dengan bahasa manusia yang menekankan pada makna atau arti (significance). Logika fuzzy dikembangkan berdasarkan bahasa manusia (bahasa alami).

\section{Fuzzy Tsukamoto}

Metode Tsukamoto merupakan perluasan dari penalaran monoton, Pada Metode Tsukamoto, setiap konsekuen pada aturan yang berbentuk IF-Then harus direpresentasikan dengan suatu himpunan fuzzy dengan fungsi keanggotaan yang monoton. Sebagai hasilnya, output hasil inferensi dari tiap-tiap aturan diberikan secara tegas (crisp) berdasarkan D-predikat (fire strength). Hasil akhirnya diperoleh dengan menggunakan rata-rata terbobot. (kusumadewi dan purnomo, 2010)

Berikut ini merupakan tahapan inferensi dalam metode fuzzy tsukamoto (Hasan, 2009):

1. Fuzzyfikasi, yaitu proses untuk mengubah input sistem yang mempunyai nilai tegas menjadi variabel linguistik menggunakan fungsi keanggotaan yang disimpan dalam basis pengetahuan fuzzy.

2. Pembentukan basis pengetahuan Fuzzy (Rule dalam bentuk IF...THEN), yaitu Secara umum bentuk model Fuzzy Tsukamoto adalah IF (X IS A) and ( $Y$ IS $B$ ) and ( $Z$ IS $C$ ), dimana $A, B$, dan $C$ adalah himpunan fuzzy.

3. Mesin Inferensi, yaitu proses dengan menggunakan fungsi implikasi MIN untuk mendapatkan nilai a-predikat tiap-tiap rule $(a 1, a 2, a 3, \quad \ldots \quad a n)$. Kemudian masing-masing nilai apredikat ini digunakan untuk menghitung keluaran hasil inferensi secara tegas (crisp) masingmasing rule $(z 1, z 2, z 3, \ldots z n)$.

4. Defuzzyfikasi, dengan menggunakan metode rata-rata (Average):

$$
Z=\frac{\sum \mathrm{a} 1 . \mathrm{Z1}}{\sum \mathrm{a} 1}
$$

\section{Teknik Analisis Data}

Metode yang digunakan dalam penelitian ini adalah metode Fuzzy Tsukamoto. Pada penelitian ini, logika fuzzy digunakan untuk memperoleh output berupa nilai gizi balita. Sistem Inferensi Fuzzy merupakan suatu kerangka komputasi yang didasarkan pada teori himpunan fuzzy, aturan fuzzy berbentuk IF-THEN, dan penalaran fuzzy. Secara garis besar, diagram blok proses inferensi fuzzy menurut kusumadewi dan purnomo (2010) adalah sebagai berikut :

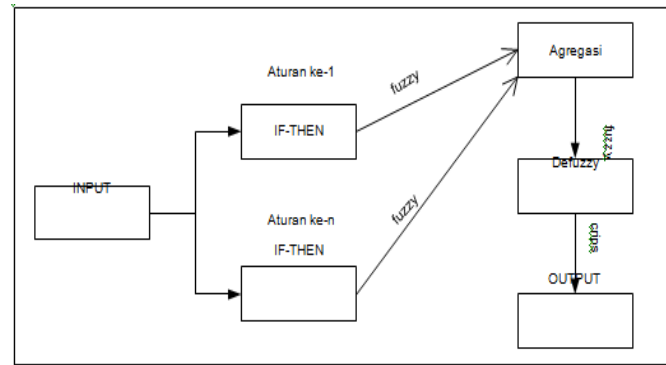

Gambar 1. Diagram Blok Sistem Inferensi Fuzzy Tsukamoto

Sistem inferensi fuzzy menerima input crisp. Input ini kemudian dikirim ke basis pengetahuan yang berisi $\mathrm{n}$ aturan fuzzy dalam bentuk IF-THEN. Fire strength akan dicari pada setiap aturan. Apabila jumlah aturan lebih dari satu, maka akan dilakukan agregasi dari semua aturan. Selanjutnya, pada hasil agregasi akan dilakukan defuzzy untuk mendapatkan nilai crisp sebagai output sistem.

Berikut ini merupakan langkah perancangan himpunan fuzzy pada sistem pendukung keputusan penanganan kesehatan balita dengan menggunakan metode tsukamoto.

1. Pembentukan Himpunan Fuzzy

Pada tahapan ini peneliti memasukkan variabel yang telah ditentukan dalam penilaian status gizi balita berdasarkan metode antropometri, yaitu Berat Badan, Tinggi Badan, Usia Balita sebagai variabel inputan dan Nilai Gizi 
sebagai variabel output. Pada metode fuzzy tsukamoto semua variabel tersebut dibagi menjadi satu atau lebih himpunan fuzzy.

2. Pembentukan Aturan Fuzzy

Setelah pembentukan variabel himpunan fuzzy, dibentuk aturan yang sesuai dengan mengambil data-data yang ada pada KMS berdasarkan metode antropometri untuk menentukan Penilaian Status Gizi Balita.

\section{Hasil dan Pembahasan}

Dalam mengolah hasil penelitian, penulis menetapkan 2 langkah penyelesaian sesuai dengan prinsip dasar pemecahan dengan menggunakan fuzzy tsukamoto, yaitu : pembentukan himpunan fuzzy dan pembentukan aturan fuzzy. Dalam Metode Fuzzy Tsukamoto, semua variabel baik itu variabel masukan maupun inputan dibagi menjadi satu atau lebih himpunan fuzzy.

Sebelum menggambarkan pembentukan himpunan fuzzy, berikut ini akan digambarkan blok sistem logika fuzzy tsukamoto untuk menetukan status gizi balita.

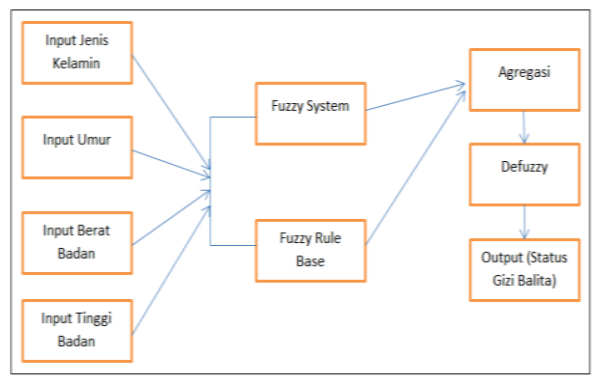

Gambar 3. Diagram Blok Sistem Informasi Fuzzy Tsukamoto Penentuan Status Gizi Balita

\subsection{Pembentukan Himpunan Fuzzy}

Pada sistem ini berbasis pengetahuan berisi kriteria pengambilan keputusan dan himpunan fuzzy masingmasing kriteria. Kriteria tersebut digolongkan menjadi himpunan bahasa variabel penentuan status gizi balita. Pada penelitian ini, dalam penentuan status gizi balita, variabel input dibagi menjadi 3 (tiga), yaitu usia (bulan), berat badan $(\mathrm{kg})$, tinggi badan $(\mathrm{cm})$. Sedangkan variabel output hanya 1 , yaitu nilai gizi. Variabel nilai gizi dibentuk berdasarkan perhitungan usia terhadap berat badan dan tinggi badan.

Penentuan variabel yang digunakan dalam penelitian ini adalah seperti yang terlihat pada tabel 1 dan 2 berikut ini :

Tabel 1. Semesta Pembicaraan Untuk Balita dengan Jenis Kelamin Laki-laki

\begin{tabular}{|c|l|c|}
\hline Fungsi & Nama Variabel & $\begin{array}{c}\text { Semesta } \\
\text { Pembicaraan }\end{array}$ \\
\hline \multirow{3}{*}{ Input } & Usia (bulan) & {$[0,60]$} \\
\cline { 2 - 3 } & $\begin{array}{l}\text { Berat badan } \\
(\mathrm{kg})\end{array}$ & {$[0,28]$} \\
\cline { 2 - 3 } & $\begin{array}{l}\text { Tinggi Badan } \\
(\mathrm{cm})\end{array}$ & {$[0,120]$} \\
\hline Output & Nilai Gizi & {$[43,82]$} \\
\hline
\end{tabular}

Tabel 2. Semesta Pembicaraan Untuk Balita dengan Jenis Kelamin Perempuan

\begin{tabular}{|c|l|c|}
\hline Fungsi & Nama Variabel & $\begin{array}{c}\text { Semesta } \\
\text { Pembicaraan }\end{array}$ \\
\hline \multirow{3}{*}{ Input } & Usia (bulan) & {$[0,60]$} \\
\cline { 2 - 3 } & $\begin{array}{l}\text { Berat badan } \\
\text { (kg) }\end{array}$ & {$[0,29]$} \\
\cline { 2 - 3 } & $\begin{array}{l}\text { Tinggi Badan } \\
(\mathrm{cm})\end{array}$ & {$[0,120]$} \\
\hline Output & Nilai Gizi & {$[43,83]$} \\
\hline
\end{tabular}

Dari variabel yang telah ditentukan pada tabel 1 dan tabel 2, kemudian dibuat domain himpunan fuzzy. Domain himpunan fuzzy merupakan keseluruhan nilai yang diperbolehkan untuk dioperasikan dalam sebuah himpunan fuzzy. Nilai domain dapat berupa bilangan positif maupun negatif.

Selanjutnya, berdasarkan domain tersebut, akan ditentukan fungsi keanggotaan dari masing-masing variabel. Berikut ini adalah rancangan dari himpunan fuzzy pada penentuan status gizi balita, seperti yang terlihat pada tabel 3 dan tabel 4. 
Tabel 3. Himpunan Fuzzy Balita Laki-laki

\begin{tabular}{|c|l|c|l|c|}
\hline Variabel & Himpunan & Domain & Fungsi Keanggotaan & Parameter \\
\hline \multirow{4}{*}{ Usia (bulan) } & Tahap 1 & {$[0,12]$} & Bahu Kiri & {$[0 ; 6 ; 12]$} \\
\cline { 2 - 5 } & Tahap 2 & {$[6,24]$} & Segitiga & {$[6 ; 12 ; 24]$} \\
\cline { 2 - 5 } & Tahap 3 & {$[12,36]$} & Segitiga & {$[12 ; 24 ; 36]$} \\
\cline { 2 - 5 } & Tahap 4 & {$[24,48]$} & Segitiga & {$[24 ; 36 ; 48]$} \\
\cline { 2 - 5 } & Tahap 5 & {$[36,60]$} & Bahu Kanan & {$[36 ; 48 ; 60]$} \\
\hline \multirow{3}{*}{$\begin{array}{c}\text { Berat badan } \\
\text { (kg) }\end{array}$} & Kurang Berat & {$[0,13]$} & Bahu Kiri & {$[0 ; 7 ; 13]$} \\
\cline { 2 - 5 } & Normal & {$[7 ; 19]$} & Segitiga & {$[7 ; 13 ; 19]$} \\
\cline { 2 - 5 } & Berat Lebih & {$[13 ; 25]$} & Bahu Kanan & {$[13 ; 19 ; 25]$} \\
\hline \multirow{3}{*}{\begin{tabular}{c} 
Tingdan (cm) \\
\cline { 2 - 5 }
\end{tabular}} & Pendek & {$[0,75]$} & Bahu Kiri & {$[0 ; 49 ; 75]$} \\
\cline { 2 - 5 } & Normal & {$[49,101]$} & Segitiga & {$[49,75,101]$} \\
\cline { 2 - 5 } & Tinggi & {$[75 ; 124]$} & Segitiga & {$[75,101,124]$} \\
\hline \multirow{4}{*}{ Nilai Gizi } & Gizi Buruk & {$[0,48]$} & Bahu Kiri & {$[0 ; 43 ; 48]$} \\
\cline { 2 - 5 } & Gizi Kurang & {$[43,53]$} & Segitiga & {$[43 ; 48 ; 53]$} \\
\cline { 2 - 5 } & Normal & {$[48,70]$} & Segitiga & {$[48 ; 53 ; 70]$} \\
\cline { 2 - 5 } & Gizi Lebih & {$[53,83]$} & Segitiga & {$[53 ; 70 ; 83]$} \\
\cline { 2 - 5 } & Obesitas & {$[70 ; 123]$} & Bahu Kanan & {$[70 ; 83 ; 123]$} \\
\hline
\end{tabular}

Tabel 4. Himpunan Fuzzy Balita Perempuan

\begin{tabular}{|c|l|c|l|c|}
\hline Variabel & Himpunan & Domain & Fungsi Keanggotaan & Parameter \\
\hline \multirow{4}{*}{ Usia (bulan) } & Tahap 1 & {$[0,12]$} & Bahu Kiri & {$[0 ; 6 ; 12]$} \\
\cline { 2 - 5 } & Tahap 2 & {$[6,24]$} & Segitiga & {$[6 ; 12 ; 24]$} \\
\cline { 2 - 5 } & Tahap 3 & {$[12,36]$} & Segitiga & {$[12 ; 24 ; 36]$} \\
\cline { 2 - 5 } & Tahap 4 & {$[24,48]$} & Segitiga & {$[24 ; 36 ; 48]$} \\
\cline { 2 - 5 } & Tahap 5 & {$[36,60]$} & Bahu Kanan & {$[36 ; 48 ; 60]$} \\
\hline \multirow{3}{*}{$\begin{array}{c}\text { Berat badan } \\
(\mathrm{kg})\end{array}$} & Kurang Berat & {$[0,12]$} & Bahu Kiri & {$[0 ; 7 ; 12]$} \\
\cline { 2 - 5 } & Normal & {$[7 ; 18]$} & Segitiga & {$[7 ; 12 ; 18]$} \\
\cline { 2 - 5 } $\begin{array}{c}\text { Badan }(\mathrm{cm}) \\
\text { Tingi }\end{array}$ & Berat Lebih & {$[13 ; 26]$} & Bahu Kanan & {$[12 ; 18 ; 26]$} \\
\cline { 2 - 5 } & Nendek & {$[0,74]$} & Bahu Kiri & {$[0 ; 48 ; 74]$} \\
\cline { 2 - 5 } & Tinggi & {$[49,100]$} & Segitiga & {$[49,74,100]$} \\
\hline \multirow{4}{*}{ Nilai Gizi } & Gizi Buruk & {$[0,48]$} & Segitiga & {$[74,100,123]$} \\
\cline { 2 - 5 } & Gizi Kurang & {$[43,53]$} & Segitiga & {$[0 ; 43 ; 48]$} \\
\cline { 2 - 5 } & Normal & {$[48,70]$} & Segitiga & {$[43 ; 48 ; 53]$} \\
\cline { 2 - 5 } & Gizi Lebih & {$[53,83]$} & Segitiga & {$[48 ; 53 ; 70]$} \\
\cline { 2 - 5 } & Obesitas & {$[70 ; 123]$} & Bahu Kanan & {$[70 ; 83 ; 123]$} \\
\hline
\end{tabular}

Himpunan fuzzy beserta fungsi keanggotan dari variabel usia, berat badan, tinggi badan dan nilai gizi yang digunakan dalam menentukan status gizi balita, dapat terlihat dari penjelasan berikut ini :

\section{a. Himpunan Fuzzy Variabel Usia}

Himpunan fuzzy beserta fungsi keanggotan dari variabel usia, berat badan, tinggi badan dan nilai gizi yang digunakan dalam menentukan status gizi balita, dapat terlihat dari penjelasan berikut ini : 


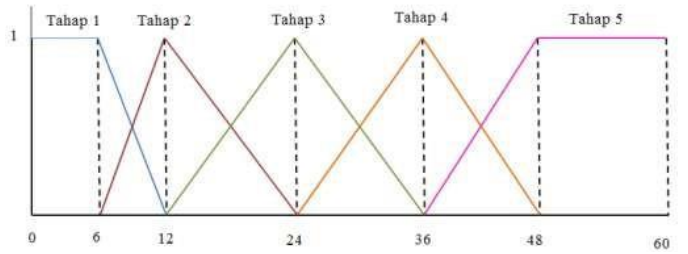

Gambar 4. Himpunan Fuzzy Variabel Usia

Sumbu horizontal pada gambar 4 menggambarkan nilai input dari variabel usia, sedangkan sumbu vertikal menggambarkan tingkat keanggotaan dari variabel yang diinput. Fungsi keanggotaan dari variabel usia adalah sebagai berikut :

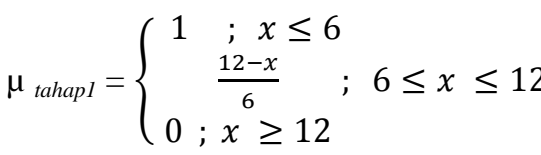

$\mu_{\text {tahap } 2}= \begin{cases}0 ; x \leq 6 \\ \frac{x-6}{6} ; \quad 6 \leq x \leq 12 \\ \frac{24-x}{12} ; \quad 12 \leq x \leq 24\end{cases}$

$\mu_{\text {tahap } 3}=\left\{\begin{array}{ccc}\frac{x-12}{12} ; & ; \quad 12 \leq x \leq 24 \\ \frac{36-x}{12} ; & 24 \leq x \leq 36\end{array}\right.$

$\mu_{\text {tahap } 4}=\left\{\begin{array}{ccc}0 & ; & x \leq 24 \\ \frac{x-24}{12} ; & ; 24 \leq x \leq 36 \\ \frac{36-x}{12} ; & 36 \leq x \leq 48\end{array}\right.$

$\mu_{\text {tahap } 5}=\left\{\begin{array}{c}0 ; x \leq 36 \\ \frac{x-36}{12} \\ 1 ; x \geq 48\end{array} ; 36 \leq x \leq 48\right.$

\section{Penjelasan :}

Seorang balita dianggap berada pada usia tahap 1 jika usia nya antara 0 bulan -12 bulan. Dianggap berada pada usia tahap 2 jika usianya antara 6 bulan sampai 24 bulan. Dianggap berada pada usia tahap 3 jika usianya antara 12 bulan sampai 36 bulan. Dianggap berada pada usia tahap 4 jika usianya antara 24 bulan sampai 48 bulan. Dianggap berada pada usia tahap 5 jika usianya antara 36 bulan sampai 60 bulan. Dianggap berada pada usia tahap 1 sekaligus tahap 2 jika usianya antara 6 bulan sampai 12 bulan. Dianggap berada pada usia tahap 2 sekaligus tahap 3 jika usianya antara 12 bulan sampai 24 bulan. Dianggap berada pada usia tahap 3 sekaligus tahap 4 jika usianya antara 24 bulan sampai 36 bulan. Dianggap berada pada usia tahap 4 sekaligus tahap 5 jika usianya antara 36 bulan sampai 48 bulan.

\section{b. Himpunan Fuzzy Variabel Berat Badan Balita Laki-laki}

Pada variabel berat badan didefinisikan 3 himpunan fuzzy, yaitu Kurang Berat, Normal, dan Berat Lebih. Untuk merepresentasikan variabel berat badan, digunakan bentuk kurva bahu kiri untuk himpunan fuzzy Kurang Berat, bentuk kurva segitiga untuk himpunan fuzzy Normal, dan bentuk bahu kanan untuk himpunan fuzzy Berat Lebih. Himpunan Fuzzy untuk variabel berat badan akan digambarkan pada gambar 5 .

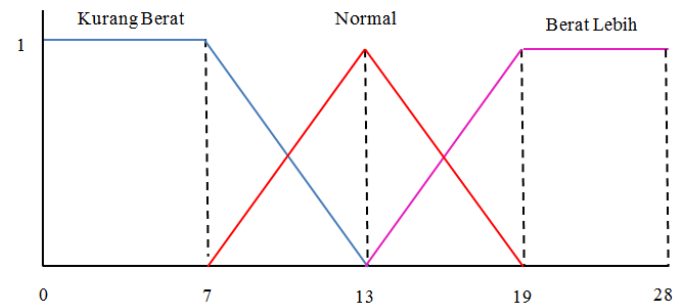

Gambar 5. Himpunan Fuzzy Variabel Berat Badan Balita Laki-laki

Sumbu horizontal pada gambar 5 menggambarkan nilai input dari variabel berat badan, sedangkan sumbu vertikal menggambarkan tingkat keanggotaan dari variabel yang diinput. Fungsi keanggotaan dari variabel berat badan adalah sebagai berikut :

$\mu_{\text {kurangberat }}=\left\{\begin{array}{c}1 \quad ; x \leq 7 \\ \frac{13-x}{6} ; 7 \leq x \leq 13 \\ 0 ; \geq 13\end{array} ; 7\right.$

$\mu_{\text {normal }}=\left\{\begin{array}{cc} & 0 ; x \leq 7 \\ \frac{x-7}{5} & ; \quad 7 \leq x \leq 13 \\ \frac{19-x}{6} & ; \quad 13 \leq x \leq 19\end{array}\right.$

$\mu_{\text {beratlebih }}=\left\{\begin{array}{c}0 \quad ; x \leq 13 \\ \frac{x-13}{6} \\ 1 ; x \geq 19\end{array} ; 13 \leq x \leq 19\right.$

Penjelasan :

Seorang balita laki-laki, dianggap kurang berat jika berat badan antara $0 \mathrm{~kg}-7$ kg. Dianggap normal jika berat badan antara $7 \mathrm{~kg}$ - $19 \mathrm{~kg}$. Dianggap berat lebih jika berat badan antara $13 \mathrm{~kg}-25 \mathrm{~kg}$. 
Dianggap kurang berat sekaligus normal jika berat badan antara $7 \mathrm{~kg}-13 \mathrm{~kg}$. Dianggap normal sekaligus berat lebih jika berat badan antara $13 \mathrm{~kg}-19 \mathrm{~kg}$.

\section{c. Himpunan Fuzzy Tinggi Badan Balita Laki-laki}

Pada variabel tinggi badan didefinisikan 3 himpunan fuzzy, yaitu Pendek, Normal, dan Tinggi. Untuk merepresentasikan variabel tinggi badan, digunakan bentuk kurva bahu kiri untuk himpunan fuzzy Pendek, bentuk kurva segitiga untuk himpunan fuzzy Normal, dan bentuk bahu kanan untuk himpunan fuzzy Tinggi. Himpunan Fuzzy untuk variabel tinggi badan akan digambarkan pada gambar 6 .

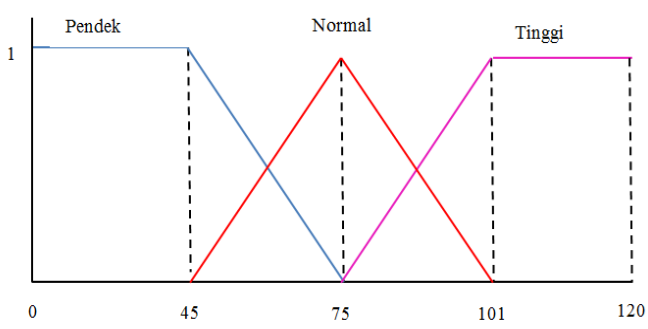

Gambar 6. Himpunan Fuzzy Variabel Tinggi Badan Balita Laki-laki

Sumbu horizontal pada gambar 6 menggambarkan nilai input dari variabel tinggi badan, sedangkan sumbu vertikal menggambarkan tingkat keanggotaan dari variabel yang diinput. Fungsi keanggotaan dari variabel tinggi badan adalah sebagai berikut :

$\mu_{\text {pendek }}=\left\{\begin{array}{c}1 \quad x \leq 49 \\ \frac{75-x}{26} \quad ; 49 \leq x \leq 75 \\ 0 ; \geq 75\end{array}\right.$
$\mu_{\text {normal }}=\left\{\begin{array}{c}\frac{x-49}{26} ; x \leq 49 \\ \frac{101-x}{26} ; 75 \leq x \leq 101\end{array}\right.$
$\mu_{\text {tinggi }}=\left\{\begin{array}{c}0 ; x \leq 75 \\ \frac{x-75}{26} ; 75 \leq x \leq 101 \\ 1 ; x \geq 101\end{array}\right.$

Penjelasan :

Seorang balita laki-laki, dianggap pendek jika tinggi badan antara $0 \mathrm{~cm}-49 \mathrm{~cm}$. Dianggap normal jika tinggi badan antara 49 $\mathrm{cm}-101 \mathrm{~cm}$. Dianggap tinggi jika tinggi badan antara $75 \mathrm{~cm}-124 \mathrm{~cm}$. Dianggap pendek sekaligus normal jika tinggi badan antara $49 \mathrm{~cm}-75 \mathrm{~cm}$. Dianggap normal sekaligus tinggi jika tinggi badan antara 75 $\mathrm{cm}-101 \mathrm{~cm}$.

\section{d. Himpunan Fuzzy Berat Badan Balita Perempuan}

Pada variabel berat badan didefinisikan 3 himpunan fuzzy, yaitu Kurang Berat, Normal, dan Berat Lebih. Untuk merepresentasikan variabel berat badan, digunakan bentuk kurva bahu kiri untuk himpunan fuzzy Kurang Berat, bentuk kurva segitiga untuk himpunan fuzzy Normal, dan bentuk bahu kanan untuk himpunan fuzzy Berat Lebih. Himpunan Fuzzy untuk variabel berat badan akan digambarkan pada gambar 7 .

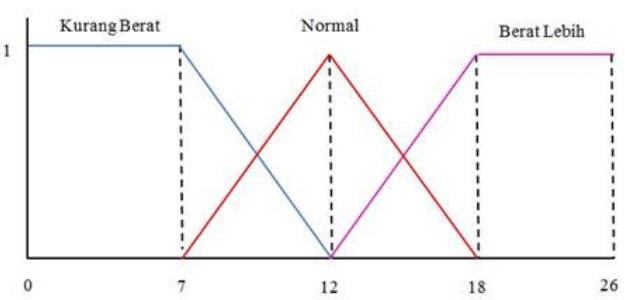

Gambar 7. Himpunan Fuzzy Variabel Berat Badan Balita Perempuan

Sumbu horizontal pada gambar 7 menggambarkan nilai input dari variabel berat badan, sedangkan sumbu vertikal menggambarkan tingkat keanggotaan dari variabel yang diinput. Fungsi keanggotaan dari variabel berat badan adalah sebagai berikut :

$$
\begin{aligned}
& \mu_{\text {kurangberat }}=\left\{\begin{array}{c}
1 ; x \leq 7 \\
\frac{12-x}{5} \\
0 ; \geq 12
\end{array} ; 7 \leq x \leq 12\right. \\
& \mu_{\text {normal }}=\left\{\begin{array}{cc}
0 & ; x \leq 7 \\
\frac{x-7}{5} & ; \quad 7 \leq x \leq 12 \\
\frac{18-x}{6} & ; \quad 12 \leq x \leq 18
\end{array}\right. \\
& \mu_{\text {beratlebih }}=\left\{\begin{array}{c}
0 ; x \leq 12 \\
\frac{x-12}{6} \\
1 ; x \geq 18
\end{array} ; 12 \leq x \leq 18\right.
\end{aligned}
$$

Penjelasan :

Seorang balita perempuan, dianggap kurang berat jika berat badan antara 0 $\mathrm{kg}-7 \mathrm{~kg}$. Dianggap normal jika berat badan antara $7 \mathrm{~kg}-18 \mathrm{~kg}$. Dianggap berat lebih jika berat badan antara $12 \mathrm{~kg}-26 \mathrm{~kg}$. 
Dianggap kurang berat sekaligus normal jika berat badan antara $7 \mathrm{~kg}-12 \mathrm{~kg}$. Dianggap normal sekaligus berat lebih jika berat badan antara $13 \mathrm{~kg}-18 \mathrm{~kg}$.

\section{e. Himpunan Fuzzy Tinggi Badan Balita \\ Perempuan}

Pada variabel tinggi badan didefinisikan 3 himpunan fuzzy, yaitu Pendek, Normal, dan Tinggi. Untuk merepresentasikan variabel tinggi badan, digunakan bentuk kurva bahu kiri untuk himpunan fuzzy Pendek, bentuk kurva segitiga untuk himpunan fuzzy Normal, dan bentuk bahu kanan untuk himpunan fuzzy Tinggi. Himpunan Fuzzy untuk variabel tinggi badan akan digambarkan pada gambar 8 .

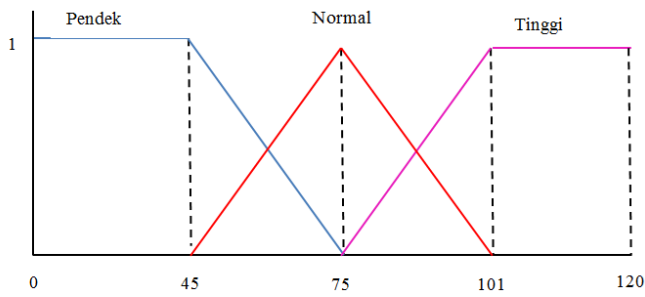

Gambar 8. Himpunan Fuzzy Variabel Tinggi Badan Balita Perempuan

Sumbu horizontal pada gambar 8 menggambarkan nilai input dari variabel tinggi badan, sedangkan sumbu vertikal menggambarkan tingkat keanggotaan dari variabel yang diinput. Fungsi keanggotaan dari variabel tinggi badan adalah sebagai berikut :

$\mu_{\text {pendek }}=\left\{\begin{array}{c}1 \quad ; x \leq 48 \\ \frac{74-x}{26} \\ 0 ; \geq 74\end{array} ; 48 \leq x \leq 74\right.$

$\mu_{\text {normal }}= \begin{cases}0 ; x \leq 48 \\ \frac{x-48}{26} \quad ; \quad 48 \leq x \leq 74 \\ \frac{100-x}{26} \quad ; \quad 74 \leq x \leq 100\end{cases}$

$\mu_{\text {tinggi }}=\left\{\begin{array}{c}0 ; x \leq 74 \\ \frac{x-74}{26} \\ 1 ; x \geq 100\end{array} ; 74 \leq x \leq 100\right.$

Penjelasan :

Seorang balita perempuan, dianggap pendek jika tinggi badan antara $0 \mathrm{~cm}-48$ $\mathrm{cm}$. Dianggap normal jika tinggi badan antara $48 \mathrm{~cm}-100 \mathrm{~cm}$. Dianggap tinggi jika tinggi badan antara $74 \mathrm{~cm}-123 \mathrm{~cm}$.
Dianggap pendek sekaligus normal jika tinggi badan antara $48 \mathrm{~cm}-74 \mathrm{~cm}$. Dianggap normal sekaligus tinggi jika tinggi badan antara $74 \mathrm{~cm}-100 \mathrm{~cm}$.

\section{f. Himpunan Fuzzy Nilai Gizi}

Pada variabel nilai gizi didefinisikan 5 himpunan fuzzy, yaitu gizi buruk, gizi kurang, normal, gizi lebih dan obesitas. Untuk merepresentasikan variabel nilai gizi, digunakan bentuk kurva bahu kiri untuk himpunan fuzzy gizi buruk, bentuk kurva segitiga untuk himpunan fuzzy gizi kurang, normal dan gizi lebih, dan bentuk bahu kanan untuk himpunan fuzzy obesitas. Himpunan Fuzzy untuk variabel usia akan digambarkan pada gambar 9 .

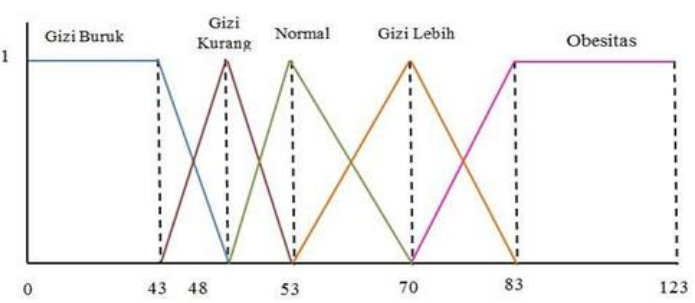

Gambar 9. Himpunan Fuzzy Variabel Nilai Gizi

Sumbu horizontal pada gambar 9 menggambarkan nilai input dari variabel nilai gizi, sedangkan sumbu vertikal menggambarkan tingkat keanggotaan dari variabel yang diinput. Nilai gizi diperoleh dari nilai Berat Badan $(\mathrm{kg}) /$ Tinggi Badan $(\mathrm{m})$. Fungsi keanggotaan dari variabel nilai gizi adalah sebagai berikut :

$$
\begin{aligned}
& \mu_{\text {giziburuk }}=\left\{\begin{array}{c}
1 \quad x \leq 43 \\
\frac{48-x}{5} \quad ; 43 \leq x \leq 48 \\
0 ; x \geq 48
\end{array}\right. \\
& \mu_{\text {gizikurang }}=\left\{\begin{array}{cc}
\frac{x-43}{5} ; & ; \quad 43 \leq x \leq 48 \\
\frac{53-x}{5} ; & 48 \leq x \leq 53
\end{array}\right. \\
& \mu_{\text {normal }}=\left\{\begin{array}{cc}
\frac{x-48}{12} ; & ; \quad 48 \leq x \leq 53 \\
\frac{70-x}{17} ; & 53 \leq x \leq 70
\end{array}\right. \\
& \mu_{\text {gizilebih }}=\left\{\begin{array}{cc}
\frac{x-53}{17} ; & ; \quad x \leq 53 \leq x \leq 70 \\
\frac{83-x}{13} ; & 70 \leq x \leq 83
\end{array}\right. \\
& \mu_{\text {obesitas }}=\left\{\begin{array}{cc}
0 ; x \leq 70 \\
\frac{x-70}{13} \quad ; \quad 70 \leq x \leq 83 \\
1 ; x \geq 83
\end{array}\right.
\end{aligned}
$$


Penjelasan :

Seorang balita akan dianggap memiliki status gizi buruk apabila nilai gizi antara 0 48. Dianggap memiliki status gizi kurang apabila nilai gizi antara 43 - 53. Dianggap memiliki status gizi normal apabila nilai gizi antara 48 - 70. Dianggap memiliki status gizi lebih apabila nilai gizi antara 53 - 83. Dianggap memiliki status gizi obesitas apabila nilai gizi antara 70 - 123 . Dianggap memiliki status gizi buruk sekaligus gizi kurang apabila nilai gizi antara 43 - 48. Dianggap memiliki status gizi kurang sekaligus normal apabila nilai gizi antara 48 - 53. Dianggap memiliki status gizi normal sekaligus gizi lebih apabila nilai gizi antara 53 - 70. Dianggap memiliki status gizi lebih sekaligus obesitas apabila nilai gizi antara $70-83$.

\subsection{Pembentukan Aturan Fuzzy}

Setelah himpunan fuzzy dibentuk, tahap berikutnya adalah akan dibuat pembentukan aturan fuzzy. Atuan-aturan tersebut dibentuk untuk menyatakan relasi yang akan terbentuk antara variabel input dan output. Tiap aturan yang terbentuk merupakan suatu implikasi. Operator yang digunakan untuk menghubungkan beberapa input adalah $A N D$, dan yang memetakan antara input-output adalah IF-THEN. Proposisi yang mengikuti IF disebut antesden, sedangkan yang mengikuti THEN disebut konsekuen.

Berdasarkan data yang ada dalam KMS, maka dapat dibentuk aturan-aturan sebagai berikut :

Tabel 5. Aturan Dalam Penentuan Status Gizi Tahap 1

\begin{tabular}{cccccc}
\cline { 3 - 5 } & & \multicolumn{3}{c}{ Berat Badan } \\
\cline { 3 - 5 } & & Kurang Berat & Normal & Berat Lebih \\
\hline \multirow{3}{*}{ Tahap 1 } & $\begin{array}{l}\text { Tinggi } \\
\text { Badan }\end{array}$ & Pendek & Normal & Gizi Lebih & Gizi Lebih \\
\cline { 3 - 5 } & & Normal & Normal & Gizi Lebih & Gizi Lebih \\
\cline { 3 - 5 } & Tinggi & Gizi Kurang & Gizi Lebih & Obesitas \\
\hline
\end{tabular}

Berdasarkan tabel 5, maka aturan Fuzzy yang terbentuk pada tahap 1 adalah sebagai berikut :

[R1] : JIKA berat badan adalah kurang berat DAN tinggi badan adalah pendek, MAKA status gizinya adalah normal. [R2] : JIKA berat badan adalah kurang berat DAN tinggi badan adalah normal, MAKA status gizinya adalah normal.
[R3] : JIKA berat badan adalah kurang berat DAN tinggi badan adalah tinggi, MAKA status gizinya adalah gizi kurang.

[R4] : JIKA berat badan adalah normal DAN tinggi badan adalah pendek, MAKA status gizinya adalah gizi lebih.

[R5] : JIKA berat badan adalah normal DAN tinggi badan adalah normal, MAKA status gizinya adalah gizi lebih

[R6] : JIKA berat badan adalah normal DAN tinggi badan adalah tinggi, MAKA status gizinya adalah gizi lebih

[R7] : JIKA berat badan adalah berat lebih DAN tinggi badan adalah pendek, MAKA status gizinya adalah gizi lebih

[R8] : JIKA berat badan adalah berat lebih DAN tinggi badan adalah normal, MAKA status gizinya adalah gizi lebih

[R9] : JIKA berat badan adalah berat lebih DAN tinggi badan adalah tinggi, MAKA status gizinya adalah obesitas

Tabel 6. Aturan Dalam Penentuan Status Gizi Tahap 2

\begin{tabular}{cccccc} 
& & & \multicolumn{3}{c}{ Berat Badan } \\
\cline { 3 - 5 } & & & Kurang Berat & Normal & Berat Lebih \\
\hline \multirow{3}{*}{ Tahap 2 } & $\begin{array}{l}\text { Tinggi } \\
\text { Badan }\end{array}$ & Pendek & Gizi Kurang & Normal & Gizi Lebih \\
\cline { 3 - 6 } & & Normal & Gizi Kurang & Normal & Gizi Lebih \\
\cline { 3 - 6 } & & Tinggi & Gizi Kurang & Normal & Obesitas \\
\hline
\end{tabular}

Berdasarkan tabel 6, maka aturan Fuzzy yang terbentuk pada tahap 2 adalah sebagai berikut :

[R10] : JIKA berat badan adalah kurang berat DAN tinggi badan adalah pendek, MAKA status gizinya adalah gizi kurang [R11] : JIKA berat badan adalah kurang berat DAN tinggi badan adalah normal, MAKA status gizinya adalah gizi kurang [R12] : JIKA berat badan adalah kurang berat DAN tinggi badan adalah tinggi, MAKA status gizinya adalah gizi kurang [R13] : JIKA berat badan adalah normal DAN tinggi badan adalah pendek, MAKA status gizinya adalah normal

[R14] : JIKA berat badan adalah normal DAN tinggi badan adalah normal, MAKA status gizinya adalah normal

[R15] : JIKA berat badan adalah normal DAN tinggi badan adalah tinggi, MAKA status gizinya adalah normal

[R16] : JIKA berat badan adalah berat lebih DAN tinggi badan adalah pendek, MAKA status gizinya adalah gizi lebih

[R17] : JIKA berat badan adalah berat lebih DAN tinggi badan adalah normal, MAKA status gizinya adalah gizi lebih 
[R18] : JIKA berat badan adalah berat lebih DAN tinggi badan adalah tinggi, MAKA status gizinya adalah obesitas

Tabel 7. Aturan Dalam Penentuan Status Gizi Tahap 3

\begin{tabular}{cccccc}
\cline { 3 - 5 } & & \multicolumn{3}{c}{ Berat Badan } \\
\cline { 3 - 5 } & & Kurang Berat & Normal & Berat Lebih \\
\hline \multirow{3}{*}{ Tahap 3 } & $\begin{array}{l}\text { Tinggi } \\
\text { Badan }\end{array}$ & Pendek & Gizi Buruk & Normal & Gizi Lebih \\
\cline { 3 - 6 } & & Normal & Gizi Buruk & Normal & Gizi Lebih \\
\cline { 3 - 6 } & & Tinggi & Gizi Buruk & Normal & Obesitas \\
\hline
\end{tabular}

Berdasarkan tabel 7, maka aturan Fuzzy yang terbentuk pada tahap 3 adalah sebagai berikut :

[R19] : JIKA berat badan adalah kurang berat DAN tinggi badan adalah pendek, MAKA status gizinya adalah gizi buruk [R20] : JIKA berat badan adalah kurang berat DAN tinggi badan adalah normal, MAKA status gizinya adalah gizi buruk [R21] : JIKA berat badan adalah kurang berat DAN tinggi badan adalah tinggi, MAKA status gizinya adalah normal [R22] : JIKA berat badan adalah normal DAN tinggi badan adalah pendek, MAKA status gizinya adalah normal

[R23] : JIKA berat badan adalah normal DAN tinggi badan adalah normal, MAKA status gizinya adalah normal

[R24] : JIKA berat badan adalah normal DAN tinggi badan adalah tinggi, MAKA status gizinya adalah normal

[R25] : JIKA berat badan adalah berat lebih DAN tinggi badan adalah pendek, MAKA status gizinya adalah gizi lebih

[R26] : JIKA berat badan adalah berat lebih DAN tinggi badan adalah normal, MAKA status gizinya adalah gizi lebih [R27] : JIKA berat badan adalah berat lebih DAN tinggi badan adalah tinggi, MAKA status gizinya adalah obesitas

Tabel 8. Aturan Dalam Penentuan Status Gizi Tahap 4

\begin{tabular}{cccccc}
\cline { 3 - 5 } & & \multicolumn{3}{c}{ Berat Badan } \\
\cline { 3 - 5 } & & Kurang Berat & Normal & Berat Lebih \\
\hline \multirow{3}{*}{ Tahap 4 } & $\begin{array}{l}\text { Tinggi } \\
\text { Badan }\end{array}$ & Pendek & Gizi Kurang & Normal & Gizi Lebih \\
\cline { 3 - 5 } & & Normal & Gizi Kurang & Normal & Gizi Lebih \\
\cline { 3 - 5 } & Tinggi & Gizi Kurang & Normal & Normal \\
\hline
\end{tabular}

Berdasarkan table 8, maka aturan Fuzzy yang terbentuk pada tahap 4 adalah sebagai berikut :
[R28] : JIKA berat badan adalah kurang berat DAN tinggi badan adalah pendek, MAKA status gizinya adalah gizi kurang [R29] : JIKA berat badan adalah kurang berat DAN tinggi badan adalah normal, MAKA status gizinya adalah gizi kurang [R30] : JIKA berat badan adalah kurang berat DAN tinggi badan adalah tinggi, MAKA status gizinya adalah gizi kurang [R31] : JIKA berat badan adalah normal DAN tinggi badan adalah pendek, MAKA status gizinya adalah normal

[R32] : JIKA berat badan adalah normal DAN tinggi badan adalah normal, MAKA status gizinya adalah normal

[R33] : JIKA berat badan adalah normal DAN tinggi badan adalah tinggi, MAKA status gizinya adalah normal

[R34] : JIKA berat badan adalah berat lebih DAN tinggi badan adalah pendek, MAKA status gizinya adalah gizi lebih

[R35] : JIKA berat badan adalah berat lebih DAN tinggi badan adalah normal, MAKA status gizinya adalah gizi lebih

[R36] : JIKA berat badan adalah berat lebih DAN tinggi badan adalah tinggi, MAKA status gizinya adalah normal

Tabel 9. Aturan Dalam Penentuan Status Gizi Tahap 5

\begin{tabular}{cccccc}
\cline { 3 - 5 } & & \multicolumn{3}{c}{ Berat Badan } \\
\cline { 3 - 5 } & & Kurang Berat & Normal & Berat Lebih \\
\hline \multirow{3}{*}{ Tahap 5 } & $\begin{array}{l}\text { Tinggi } \\
\text { Badan }\end{array}$ & Pendek & Gizi Buruk & Gizi Kurang & Gizi Lebih \\
\cline { 3 - 5 } & & Normal & Gizi Buruk & Gizi Kurang & Gizi Lebih \\
\cline { 3 - 6 } & & Tinggi & Gizi Buruk & Gizi Kurang & Normal \\
\hline
\end{tabular}

Berdasarkan table 9, maka aturan Fuzzy yang terbentuk pada tahap 5 adalah sebagai berikut :

[R37] : JIKA berat badan adalah kurang berat DAN tinggi badan adalah pendek, MAKA status gizinya adalah gizi buruk [R38] : JIKA berat badan adalah kurang berat DAN tinggi badan adalah normal, MAKA status gizinya adalah gizi buruk [R39] : JIKA berat badan adalah kurang berat DAN tinggi badan adalah tinggi, MAKA status gizinya adalah gizi buruk [R40] : JIKA berat badan adalah normal DAN tinggi badan adalah pendek, MAKA status gizinya adalah gizi kurang

[R41] : JIKA berat badan adalah normal DAN tinggi badan adalah normal, MAKAstatus gizinya adalah gizi kurang 
[R42] : JIKA berat badan adalah normal DAN tinggi badan adalah tinggi, MAKA status gizinya adalah gizi kurang

[R43] : JIKA berat badan adalah berat lebih DAN tinggi badan adalah pendek, MAKA status gizinya adalah gizi lebih

[R44] : JIKA berat badan adalah berat lebih DAN tinggi badan adalah normal, MAKA status gizinya adalah gizi lebih [R45] : JIKA berat badan adalah berat lebih DAN tinggi badan adalah tinggi, MAKA status gizinya adalah normal

\subsection{Implementasi Algoritma}

Misalkan ada balita dengan data sebagai berikut :

$\begin{array}{ll}\text { Usia } & : 22 \text { bulan } \\ \text { Bobot } & : 15 \mathrm{Kg} \\ \text { Panjang Badan } & : 95 \mathrm{~cm}\end{array}$

a. Proses Fuzzyfikasi

Mencari nilai derajat keanggotaan :

1) Variabel Umur

Termasuk dalam fase 2 dan fase 3

Umur 22 Bulan untuk fase 2 :

$\mu 22:(24-22) / 12=0,16666$

Umur 22 Bulan untuk fase 3 : $\mu 22:(22-12) / 12=0,83333$

2) Variabel Berat Badan

Termasuk dalam bobot "Normal" dan "Berat Lebih"

Berat Badan $16 \mathrm{~kg}$ untuk fase normal:

unormal : $(19-15) / 6=0,66667$

uberat lebih : $(15-13) / 6=0,33333$

3) Variabel Panjang Badan $95 \mathrm{~cm}$

Termasuk kedalam fase Normal dan Tinggi

unormal : (101-95)/26 $=0,2307$

$\mu$ tinggi : $(95-75) / 26=0,9615$

b. Proses Inferensi

Dari hasil fuzzy diatas didapat :

- $\quad$ Fase $2(0,1666)$

- Fase $3(0,8333)$

- Bobot Normal $((0,66667)$

- $\quad$ Bobot Berat Lebih $(0,33333)$

- $\quad$ Tinggi Badan Normal $(0,2307)$

- $\quad$ Tinggi Badan Tinggi $(0,9615)$

Dari hasil proses fuzzyfikasi dan inferensi di atas, maka didapat 8 rule yang sesuai :

Fase $2:(0,1666)$

[R14] : JIKA berat badan adalah normal $(0,66667)$ DAN tinggi badan adalah normal $(0,2307)$, MAKA status gizinya adalah normal

[R15] : JIKA berat badan adalah normal $(0,66667)$ DAN tinggi badan adalah tinggi $(0,9615)$, MAKA status gizinya adalah normal

[R17] : JIKA berat badan adalah berat lebih $(0,3333)$ DAN tinggi badan adalah normal $(0,2307)$, MAKA status gizinya adalah gizi lebih [R18] : JIKA berat badan adalah berat lebih $(0,3333)$ DAN tinggi badan adalah tinggi $(0,9615)$, MAKA status gizinya adalah obesitas

Fase $3:(0,8333)$

[R23] : JIKA berat badan adalah normal $(0,66667)$ DAN tinggi badan adalah normal $(0,2307)$, MAKA status gizinya adalah normal

[R24] JIKA berat badan adalah normal $(0,66667)$ DAN tinggi badan adalah tinggi $(0,9615)$, MAKA status gizinya adalah normal

[R26] : JIKA berat badan adalah berat lebih $(0,3333)$ DAN tinggi badan adalah normal $(0,2307)$, MAKA status gizinya adalah gizi lebih [R27] : JIKA berat badan adalah berat lebih $(0,3333)$ DAN tinggi badan adalah tinggi $(0,9615)$, MAKA status gizinya adalah obesitas

Tabel 10 Nilai Akhir

\begin{tabular}{|c|c|c|c|c|}
\hline Rule & $\begin{array}{c}\text { Status } \\
\text { Gizi }\end{array}$ & $\begin{array}{c}\text { Alpha } \\
\text { Min }\end{array}$ & Z & alpha*z \\
\hline $\mathrm{R} 14$ & Normal & 0,1666 & 50 & 8,33 \\
\hline R15 & Normal & 0,1666 & 50 & 8,33 \\
\hline R17 & Gizi Lebih & 0,1666 & 55,83 & 9,301278 \\
\hline $\mathrm{R} 18$ & Obesitas & 0,1666 & 85,16 & 14,18766 \\
\hline $\mathrm{R} 23$ & Normal & 0,2307 & 50,77 & 11,71264 \\
\hline $\mathrm{R} 24$ & Normal & 0,6667 & 56 & 37,3352 \\
\hline $\mathrm{R} 27$ & Gizi Lebih & 0,2307 & 56,92 & 13,13144 \\
\hline $\mathrm{R} 28$ & Obesitas & 0,3333 & 74,33 & 24,77419 \\
\hline \multicolumn{2}{|c|}{ Total Akhir } & 2,1278 & & 127,1024 \\
\hline
\end{tabular}

Maka Hasil Akhirnya adalah 27,1024/2,1278 $=59,73419$.

Jadi dengan menggunakan metode fuzzy tsukamoto, seorang balita berumur 22 bulan dengan berat $15 \mathrm{~kg}$ dan tinggi $95 \mathrm{~cm}$ termasuk dalam gizi normal dengan besaran nilai gizi 59,73 . 


\section{Kesimpulan}

Berdasarkan hasil analisa dan pengolahan data yang telah penulis lakukan, maka dapat diperoleh kesimpulan sistem penunjang keputusan dalam penentuan status gizi balita adalah metode fuzzy tsukamoto. Kriteria pengolahan data yang digunakan adalah jenis kelamin, usia, berat badan dan tinggi badan. Hasil akhir yang diharapkan adalah diperoleh status gizi balita berdasarkan berat badan dan tinggi badan. Hasil yang diperoleh dari pembentukan himpunan fuzzy dan pembentukan aturan fuzzy adalah terdapat 45 rules untuk penentuan status gizi balita. Setelah dilakukan uji sample terhadap data yang diperoleh, didapatkan hasil bahwa tingkat keberhasilan aturan fuzzy tsukamoto yang telah terbentuk dalam penentuan status gizi balita adalah $82,35 \%$. Saran yang dapat penulis sampaikan dalam penelitian ini adalah penelitian ini dapat digunakan untuk penelitian dengan metode fuzzy yang berbeda dengan kasus yang sama yaitu untuk menentukan status gizi balita.

\section{Referensi}

Fidiantoro, N., \& Setiadi, T. (2013). Model Penentuan Status Gizi Balita Di Puskesmas. Jurnal Sarjana Teknik Informatika Volume 1 Nomor 1, Juni 2013 e-ISSN : 2338-5197, 367-373.

Fitri, O. S., \& Rahardi S, D. (2013). Aplikasi Jaringan Syaraf Tiruan Untuk Penentuan Status Gizi Balita Dan Rekomendasi Menu Makanan Yang Dibutuhkan. Jurnal EECCIS Vol. 7, No. 2, Desember 2013, 119-124.

Hasan, M. (2009). Pokok-pokok Materi Statistik 1. Jakarta: Bumi Aksara.

Kusrini. (2007). Konsep dan Aplikasi Sistem Pendukung Keputusan. Yogyakarta: Penerbit Andi.

Kusumadewi, S., \& Purnomo, H. (2004). Aplikasi Logika Fuzzy untuk Pendukung Keputusan. Yogyakarta: Graha IImu.

Rahim, F. K. (2014). Faktor Risiko Underweightbalita Umur 7-59 Bulan. Jurnal Kesehatan Masyarakat. ISSN 1858-1196, 115-121.
Romadhon, A., \& Purnomo, A. S. (2016). Sistem Penunjang Keputusan Untuk Menentukan Status Gizi Balita Menggunakan Metode Fuzzy Inferensi Sugeno. Informatics Journal. Vol. 1 No.3. ISSN : 2503250-X, 78-87.

Supariasa. (2001). Penilaian Status Gizi. Jakarta: EGC.

Turban, E., Aronson, J., \& Liang, T. (2005). Decision Support System and Intelligence System 7th Edition. Prentice Education International. 